\title{
Reintroduction of the invasive mosquito Aedes aegypti (Linnaeus) (Diptera: Culicidae) in northern Chile
}

\author{
Reintroducción del invasivo mosquito Aedes aegypti \\ (Linnaeus) (Diptera: Culicidae) en el norte de Chile \\ Christian R. González ${ }^{1 *}$, Abel Henry ${ }^{2}$, Carolina Reyes ${ }^{1}$, María Paz Aylwin ${ }^{1}$, \\ Daniel Escobar ${ }^{1}$, Jorge Fernández ${ }^{3}$, Mónica Saldarriaga-Córdoba ${ }^{4,5}$
}

\begin{abstract}
Historically, Aedes aegypti (L.) was present in northern Chile between the cities of Arica $\left(18^{\circ} 28^{\prime} \mathrm{S} / 70^{\circ} 18^{\prime} \mathrm{W}\right)$ and Caldera ( $27^{\circ} 03^{\prime}$ S $\left./ 70^{\circ} 49^{\prime} \mathrm{W}\right)$. It was eradicated from northern Chile in the 1950s by the use of DDT. In April 2016, Aedes aegypti (L.) was once again detected in northern Chile after an absence of more than 60 years. This finding suggests a reintroduction of the species to northern Chile or a dispersal from an adjacent country (or both). Given the immense importance of this mosquito as a vector of flaviviruses (i.e. yellow fever, dengue, Chikungunya, Zika), this recurrence presents a new challenge for public health authorities in Chile.

Key words: mosquito, mitochondrial DNA, colonization, arid environments, vector.
\end{abstract}

\section{RESUMEN}

Aedes aegypti ( $L$ ) estuvo presente en el norte de Chile entre las ciudades de Arica (18 $\left.28^{\prime} \mathrm{S} / 70^{\circ} 18^{\prime} \mathrm{W}\right)$ y Caldera $\left(27^{\circ} 03^{\prime} \mathrm{S} / 70^{\circ} 49^{\prime} \mathrm{W}\right)$ pero fue erradicado con el uso del DDT en la década de 1950. En abril de 2016 fue nuevamente detectado después de una ausencia de más de 60 años. El encuentro de esta especie sugiere su reintroducción al norte de Chile o una dispersión desde un país fronterizo (o ambos). Dada la tremenda importancia de esta especie como vector de flavivirus (por ejemplo, Fiebre Amarilla, Dengue, Chikungunya y Zika) esta reintroducción representa un nuevo escenario para la salud pública de Chile y sus autoridades.

Palabras clave: mosquitos, ADN mitocondrial, colonización, medio ambientes áridos, vector.

\section{Introduction}

Dengue virus is the most common vectorborne viral disease of humans worldwide, with an estimated 50 million infections occurring in tropical and subtropical regions each year (Bhatt et al., 2013). Aedes aegypti (L.), the main dengue vector in the Americas, is capable of breeding in a variety of habitat types (San Martín et al., 2010).

Ae. aegypti was once distributed over a large portion of South America, but was eradicated following large-scale control campaigns (San Martín et al., 2010). Historically, Ae. aegypti was present in northern
Chile between the cities of Arica $\left(18^{\circ} 28^{\prime} \mathrm{S} / 70^{\circ} 18^{\prime} \mathrm{W}\right)$ and Caldera $\left(27^{\circ} 03^{\prime} \mathrm{S} / 70^{\circ} 49^{\prime} \mathrm{W}\right)$. Although the first record of the presence of Ae. aegypti in Chile is not known, the first documented case of dengue was in 1890 (Laval, 2003). House to-house spraying with DDT in the 1950s eliminated Ae. aegypti from northern Chile, thanks to the work of Dr. Neghme who eliminated the species from continental Chile (Neghme et al., 1950, 1953). Verification and certification of the eradication in Chile was done by the Pan American Sanitary Bureau in 1961 (Soper, 1963), but by 1980 almost all the countries had been re-infested (Brathwaite et al., 2012).

\footnotetext{
Laboratorio de Entomología Médica, Sección Parasitología, Instituto de Salud Pública de Chile.

Laboratorio Agrícola Regional, Servicio Agrícola y Ganadero, Región XV Arica-Parinacota.

Subdepartamento de Genética Molecular, Instituto de Salud Pública de Chile.

Centro de Investigación en Recursos Naturales y Sustentabilidad, Universidad Bernardo O'Higgins, Fábrica 1990, segundo piso, Santiago, Chile.

5 Laboratorio de Biología y Bioinformática, Departamento de Ciencias, Universidad Iberoamericana de Ciencias y Tecnología, Santiago, Chile.

* Corresponding Author: cgonzalez@ispch.cl
}

Fecha de Recepción: 13 Julio, 2016.

Fecha de Aceptación: 30 Julio, 2016. 
Urbanization, especially unregulated growth combined with poor sanitary services, is considered a key factor underlying the proliferation of $A e$. aegypti across tropical and subtropical countries. Large portions of the Americas have warm and humid climates well suited for the proliferation of Ae. aegypti. However, the species has also been detected in arid areas like Arizona, where it has been introduced even though aridity may be a key limiting factor (Walker et al., 2011).

Ae. aegypti was originally endemic to Africa, where the ancestral form was likely a generalist, zoophilic treehole breeder. It has spread throughout tropical and subtropical regions over the last 50 years. Now the species, eminently successful in artificial containers that mimic and are much more abundant than the ancestral treehole habitat, is found in close association with human habitats throughout the tropical and subtropical world. Due to increased trade over the centuries this species was spread across the tropical and subtropical world. The species was likely introduced to the New World by slave trade ships between the $15^{\text {th }}$ and $18^{\text {th }}$ centuries, possibly on multiple occasions (Tabachnick, 1991; Barret \& Higgs, 2007).

The aim of the present study was to investigate a known reintroduction of Ae. aegypti in the city of Arica, northern Chile, after not having been detected in more than 60 years.

\section{Materials and Methods}

\section{Mosquito collection, identification, and study area}

Mosquito larvae and adults were collected in April, 2016, from a variety of breeding sites in Arica, Arica Province, Chile $\left(18^{\circ} 27^{\prime} \mathrm{S} / 70^{\circ} 16^{\prime} \mathrm{W}\right)$. The city of Arica is situated at the northern end of Chile, about $2,000 \mathrm{~km}$ from the city of Santiago and just south of the border with Peru. This region is characterized by a low rainfall regime; the landscape is arid and has little vegetation. Situated on the Pacific coast, Arica has a cloud-coastal desert climate, with abundant morning fog or "camanchaca", caused mainly by the influence of the cold Humboldt Current. Arica has an average annual temperature of $18.8^{\circ} \mathrm{C}$ and annual precipitation $<3 \mathrm{~mm}$.

Larvae and adult mosquitoes were identified and studied in the Laboratorio de Entomología Médica of the Instituto de Salud Pública de Chile; identifications were based on the descriptions and morphological keys of Darsie (1985) and Rueda (2004).

\section{DNA extraction, PCR amplification and sequencing}

Genomic DNA was extracted from one leg of a mosquito using the QIAamp DNA Mini Kit (QIAGEN, GmbH, Hilden, Germany). PCR amplification of mitochondrial cytochrome oxidase subunit I (COI) was performed using LCO1490 and HCO2198 primers (Laurito et al., 2013); the nuclear ribosomal internal transcribed spacer 2 (ITS-2) region was amplified using the $5.8 \mathrm{~S}-28 \mathrm{~S}$ primer pair (Dhananjeyan et al., 2010). The PCR products generated were sequenced in both directions with a BigDye Terminator Cycle Sequence Kit v3.1 (Applied Biosystems, Foster City, CA, USA). Nucleotide sequences were obtained via an ABI PRISM 3500 Genetic Analyzer (Applied Biosystems).

\section{Molecular identifications}

DNA sequences were edited using BioEdit version 7.0 (Hall, 1999) and Chromas 2.5.1 (http:// technelysium.com.au/wp/chromas/). We used similarity methods based on the match between the query sequence and the reference database [e.g. BLAST (http://blast.ncbi.nlm.nih.gov/Blast.cgi) and the Species Level Barcode Records Database in The Barcode of Life Data Systems (BOLDSYSTEMS: http://www.boldsystems.org) to analyze the DNA barcode region and ITS-2 of the mosquitoes collected in Arica and assign individuals to a given species. Species-level identification was considered supported if the similarity was $\geq 98 \%$ (Cywinska et al., 2006).

\section{Results and Discussion}

During April 2016, adult females and larvae of, presumably, Ae. aegypti were captured in the city of Arica. The specimens were identified morphologically and molecularly. PCR amplification the COI mitochondrial gene has been used for molecular characterization of mosquitoes, using LCO1490 and HCO2198 primers (Laurito et al., 2013). Mosquito specimens from Arica also showed specific amplification for this COI region, with a PCR product of length similar to the positive control fragment, as shown in Figure 1.

ITS-2 amplification using the $5.8 \mathrm{~S}$ and $28 \mathrm{~S}$ primers has been used before to differentiate easily 
between Aedes species, according to the specific length of PCR products (Patsoula et al 2006; Dhananjeyan et al., 2010). The amplification of the ITS2 region produced a fragment of $\sim 360$ bp for the mosquitoes from Arica, similar to the product obtained for the Ae. aegypti positive control (Easter Island), as shown in Figure 2.

\section{Molecular identification}

The sequence obtained was of $566 \mathrm{bp}$ for the barcode gene fragment (COI) and $362 \mathrm{bp}$ for the ITS fragment. The DNA sequence of the COI gene contained no stop codons, which suggests a mitochondrial origin rather than nuclear insertion.

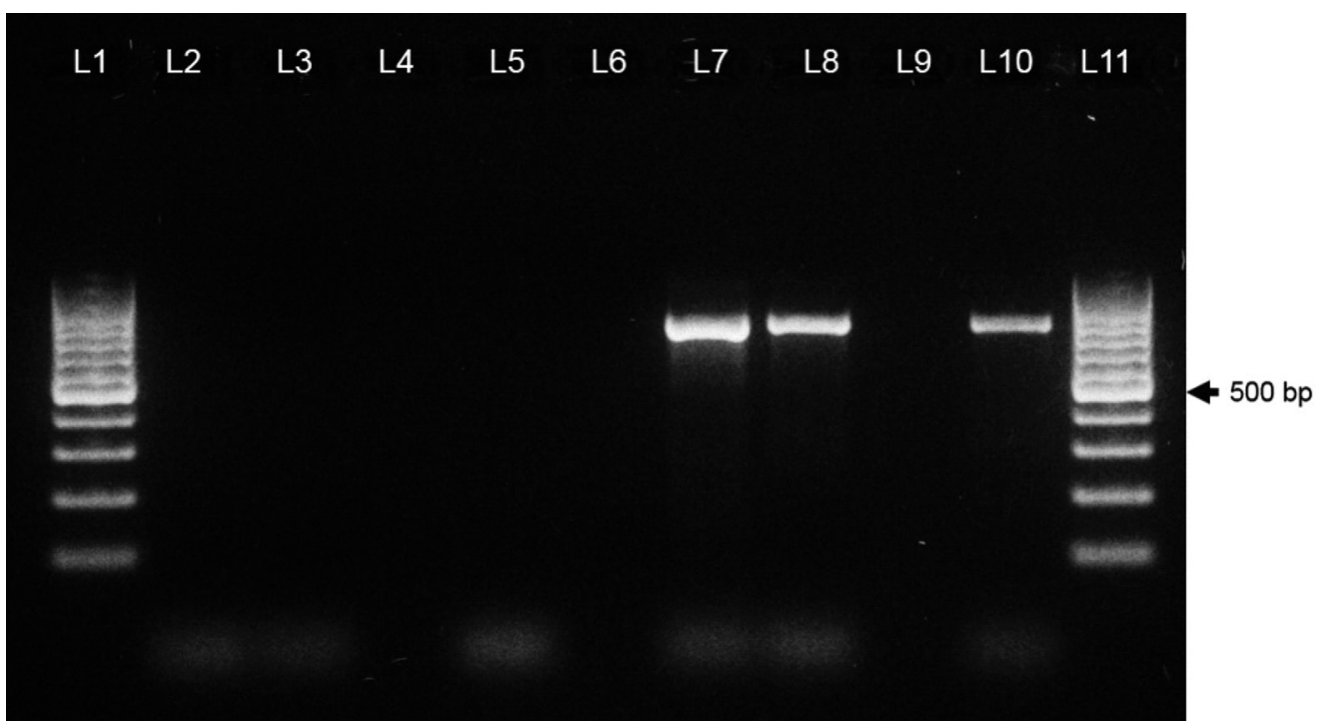

Figure 1. Gel photograph showing amplification of the COI region for identification of Mosquito species (Diptera, Culicidae), using LCO1490/HCO2198 primers. Lanes 1, 11: 100 bp DNA molecular weight marker (Invitrogen); Lanes 2, 3 and 5: Negative Controls; L7, L8: Duplicate samples; L10: Positive Control (Ae. aegypti from Easter Island).

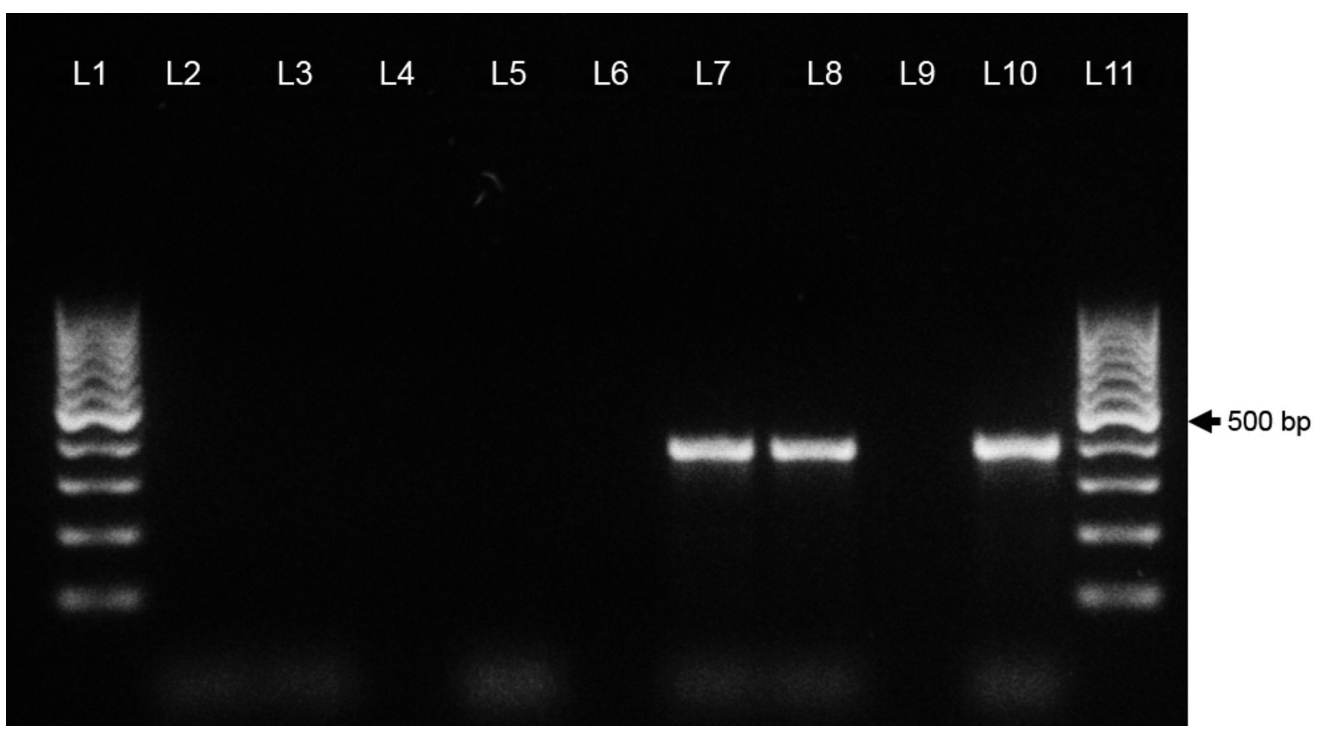

Figure 2. Gel photograph showing amplification of the ITS-2 region for identification of Aedes species, using 5.8S/28S primers. Lanes 1, 11: 100 bp DNA molecular weight marker (Invitrogen); Lanes 2, 3 and 5: Negative Controls; L7, L8: Duplicate samples; L10: Positive Control (Ae. aegypti from Easter Island). 
Its identification in the BOLD System database (COI gene) and BLAST (ITS-2) was congruent with Ae. aegypti species. The probability of placement was $100 \%$ and $99 \%$ for COI and ITS, respectively (Figures 3 and 4).

The colonization route of these specimens to Chile is not known. However, human-aided dispersal (e.g. via tires and other artificial containers bearing eggs) and the transport of mosquitoes by aircraft have been suggested by several authors, and could well be the routes of reintroduction (Guagliardo et al.,
2014). The reintroduction of this species in an area of extreme aridity such as northern Chile, reflects the ecological and physiological plasticity of Ae. aegypti.

Morphological identification is the gold standard method to identify mosquito species but may be compromised by damaged or rubbed specimens, which thereby lack key morphological characters. Complementary techniques are necessary, among which DNA barcoding is frequently suggested. In this study we used integrative taxonomy for identification the specimens collected in Arica, morphological characters

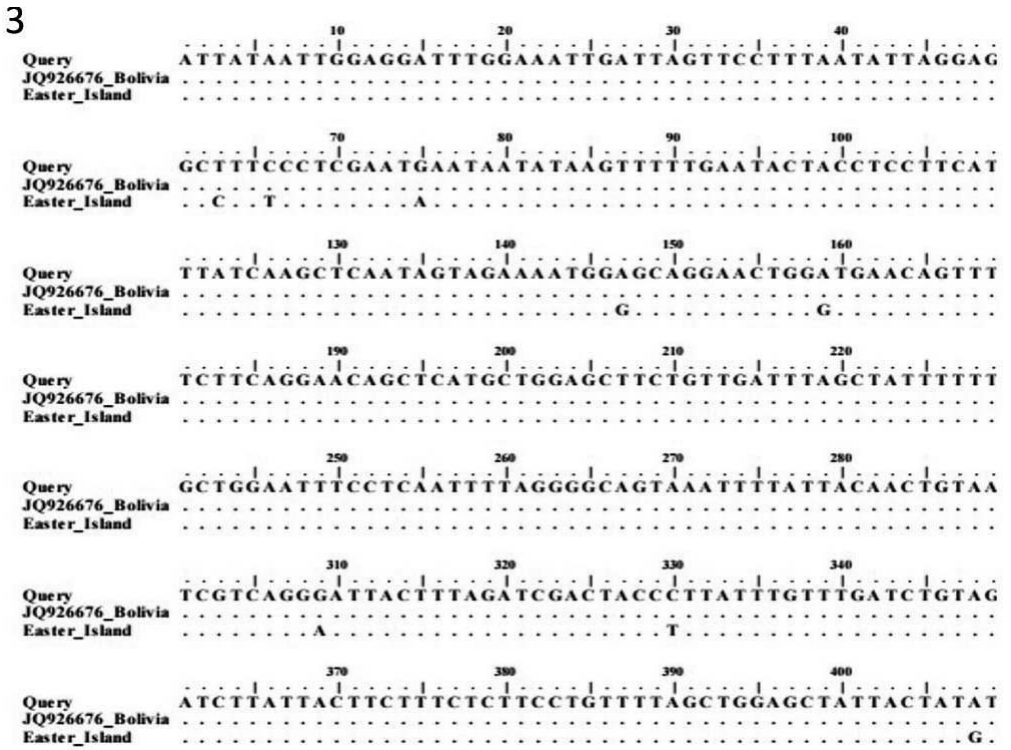

Figure 3. Multiple sequence alignment of the barcode gene (COI) of Ae. aegypti from Arica, Chile (Query) with sequences of Ae. aegypti from Easter Island (this study) and Bolivia published in the BOLD Identification System (BOLD:AAA4210). The percentage probability of placement was $100 \%$. Genetic p distance between query sequence and Ae. aegypti from Bolivia and Easter Island was 0.0\% and 2.2\% (8 mistmaches), respectively.

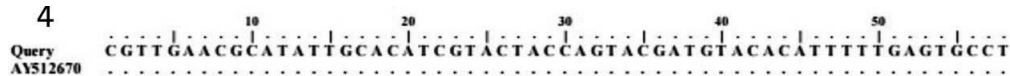

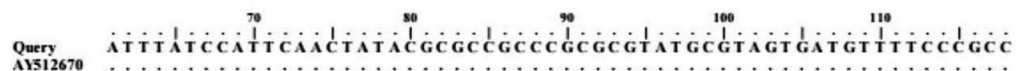

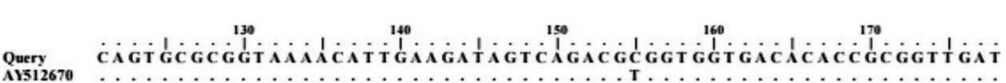

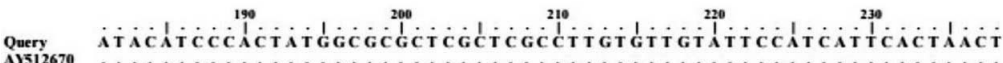

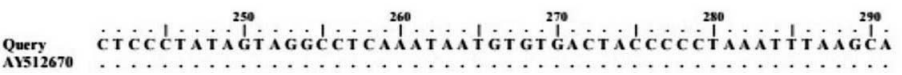

Figura 4. Pairwise sequence alignment of ITS-2 of Ae. aegypti from Arica, Chile (Query) with sequences of Ae. aegypti from Peru published in the GenBank database (AY512670). The percentage probability of placement was $99 \%$ (1 mistmach). 
and two molecular markers, one of them mitochondrial origin and the other of nuclear origin, both providing supportive evidence of a correct identification.

The reintroduction of Ae. aegypti in the city of Arica presents a new challenge for health authorities in Chile and suggests a greater need for increased surveillance and research in the region north of the country.

\section{Acknowledgements}

We thank Dr. Stephen M. Smith (Biology, University of Waterloo) for help in revising the manuscript and editing the English version and Manual Gajardo and Pamela Peña (Seremi de Salud Arica y Parinacota) for their assistance in collecting specimens.

\section{Literature Cited}

Barrett, A.D.; Higgs, S.

2007. Yellow fever: a disease that has yet to be conquered. Annual Review of Entomology, 52: 209-229.

Bhatt, S.; Gething, P.W.; Brady, O.J.; Messina, J.P.; Farlow, A.W.; Moyes, C.L.; Drake, J.M.; Brownstein, J.S.; Hoen, A.G.; Sankoh, O.; Myers, M.F.; George, D.B.; Jaenisch, T.; Wint, G.R.W.;

Simmons, C.P.; Scott, T.W.; Farrar, J.J.; Hay, S.I

2013. The global distribution and burden of dengue. Nature, 496 (7446): 504-7. doi: 10.1038/nature12060.

Brathwaite, D.O.; San Martín, J.L.; Montoya, R.H.; del Diego,

J.; Zambrano, B.; Dayan, G.

2012. The history of dengue outbreaks in the Americas. The American Journal of Tropical Medicine and Hygiene, 87: 584-593.

Cywinska, A.; Hunter, F.F.; Hebert, P.D.N

2006. Identifying Canadian mosquito species through DNA barcodes. Medical and Veterinary Entomology, 20: 413-424.

Darsie, R.F.

1985. Mosquitoes of Argentina. PART I. Keys for identification of adult females and fourth stage larvae in English and Spanish (Diptera, Culicidae). Mosquito Systematics, 17 (3): 153-253.

Dhananjeyan, K.J.; Paramasivan, R.; Tewari, S.C.; Rajendran,

R.; Thenmozhi, V.; Leo, S.V.; Venkatesh, A.; Tyagi, B.K.

2010. Molecular Identification of mosquito vectors using genomic DNA isolates from eggshells, larval and pupal exuvium. Tropical Biomedicine, 27 (1): 47-53.

Guagliardo, S.A.; Barboza, J.L.; Morrison, A.C.; Astete, H.; Vazquez-Prokopec, G.; Kitron, U.

2014. Patterns of geographic expansion of Aedes aegypti in the Peruvian Amazon. PLoS Neglected Tropical Diseases, 8 (8): e3033. doi:10.1371/journal.pntd.0003033.

Hall, T.A.

1999. BioEdit: a user-friendly biological sequence alignment editor and analysis program for windows 95/98/NT. Nucleic Acids Symposium Series, 41: 95-98.
Laurito, M.; de Oliveira, T.M.; Almirón, W.R.; Sallum, M.A.M. 2013. COI barcode versus morphological identification of Culex (Culex) (Diptera: Culicidae) species: a case study using samples from Argentina and Brazil. Memórias do Instituto Oswaldo Cruz, 108: 110-122.

Laval, E.

2003. ¿Hubo Dengue autóctono en Chile? Revista Chilena de Infectología, 20: 98-99.

Neghme, A.

1950. Control del A. aegypti en Chile. Boletín de la Oficina Sanitaria Panamericana, 29 (4): 389-396.

Neghme, A.; Albi, H.; Gutiérrez, J.

1953. Campaña de erradicación del Aedes aegypti en Chile. Boletín de la Oficina Sanitaria Panamericana, 34 (3): 205-220.

Rueda, L.E.

2004. Pictorial keys for the identification of mosquitoes (Diptera: Culicidae) associated with Dengue Virus transmission. Zootaxa, 589: 1-60.

San Martín, J.L.; Brathwaite, O.; Zambrano, B.; Solórzano, J.O.; Bouckenooghe, A.; Dayan, G.H.; Guzmán, M.G.

2010. The epidemiology of Dengue in the Americas over the last three decades: a worrisome reality. The American Journal of Tropical Medicine and Hygiene, 82 (1): 128-135.

Soper, F.L.

1963. The elimination of urban yellow fever in the Americas through the eradication of Aedes aegypti. American Journal of Public Health, 53: 7-16.

Tabachnick, W.J.

1991. Evolutionary genetics and insect borne disease. The yellow fever mosquito, Aedes aegypti. American Entomologist, 37: 14-24.

Walker, K.R.; Joy, T.K.; Ellers-Kirk, C.; Ramberg, F.B.

2011. Human and environmental factors affecting Aedes aegypti distribution in an arid urban environment. Journal of the American Mosquito Control Association, 27 (2): 135-141. 
